\title{
Cientitifica
}

http://revistas.udistrital.edu.co/ojs/index.php/revcie/index

\section{STEAM as a tool to encourage engineering studies}

\section{STEAM como herramienta para fomentar los estudios de ingeniería}

\section{STEAM como uma ferramenta para incentivar estudos de engenharia}

\author{
Maria Amparo Oliveros-Ruiz'
}

Received: February de 2019

Accepted: April de 2019

Citation: Oliveros-Ruiz, M., A. (2019). STEAM as a tool to encourage engineering studies. Revista Científica, 35(2), 158-166. Doi: https://doi.org/10.14483/23448350.14526

\begin{abstract}
In recent times women have been making their way into engineering, one of the most booming fields internationally. However, women enrollment in these careers in Mexico has grown slowly, only about 30 $\%$ of the total student population enrolled in an engineering related program are women. For the purposes of this research, a survey was applied to the students of three universities in the northwest region of Mexico conformed a STEAM network aiming to promote enrollment, retention and gender equality on STEM careers, in order to present the outcome about their motivation for this career choice. As well as the future performance model of female students enrolled in engineering degrees. Findings have shown that there is no female model to follow, so it is proposed to include a Science, Technology, Engineering, Arts and Mathematics (STEAM) model in the Schools of Engineering to increase preference and enrollment of women in this area of knowledge.
\end{abstract}

Keywords: Engineering, gender, STEM teaching, Role models.

\section{Resumen}

En los últimos tiempos, las mujeres se han estado abriendo camino hacia la ingeniería, uno de los campos más florecientes a nivel internacional. Sin embargo, la inscripción de mujeres en estas carreras en México ha crecido lentamente, solo alrededor del $30 \%$ de la población estudiantil inscrita en un programa relacionado con la ingeniería son mujeres. Para los fines de esta investigación, se aplicó una encuesta a los estudiantes de tres universidades de la región noroeste de México conformando una red STEAM con el objetivo de promover la inscripción, la retención y la igualdad de género en las carreras STEM, con el fin de presentar el resultado sobre su motivación para esta elección de carrera. Además del futuro modelo de desempeño de las alumnas matriculadas en carreras de ingeniería. Los hallazgos han demostrado que no hay un modelo femenino a seguir, por lo que se propone incluir un modelo de Ciencia, Tecnología, Ingeniería, Artes y Matemáticas (STEAM) en las escuelas de ingeniería para aumentar la preferencia y la inscripción de mujeres en esta área de conocimiento. 
Palabras clave: ingeniería, género, enseñanza STEM, modelos a seguir.

\section{Resumo}

Nos últimos tempos, as mulheres estão abrindo caminho na engenharia, um dos campos mais florescentes internacionalmente. No entanto, a matrícula de mulheres nas carreiras no México tem crescido lentamente, somente um $30 \%$ da população estudantil matriculada em um programa relacionado à engenharia são mulheres. Para os propósitos desta pesquisa, um questionário foi aplicado aos estudantes de três universidades na região noroeste do México formando uma rede STEAM com o objetivo de promover matrícula, retenção e igualdade de gênero em cursos STEM, a fim de apresentar o resultado sobre sua motivação para essa escolha de carreira. Além do modelo de desempenho futuro dos alunos matriculados em carreiras de engenharia. Os resultados mostraram que não existe um modelo feminino a seguir, por isso propõe-se incluir um modelo de Ciência, Tecnologia, Engenharia, Artes e Matemática (STEAM) em escolas de engenharia para aumentar a preferência e a inscrição de mulheres nesta área de conhecimento.

Palavras-chaves: engenharia, gênero, ensino STEM, modelos.

\section{Introduction}

The low rate of young people enrolled in the areas of Science, Technology, Engineering and Mathematics (STEM) is a major international challenge. In studies of global innovation, mainly tertiary education, the STEM fields have been identified as a critical determinant in the level of innovation Pruitt, S.L. (2014). In the case of Mexico according to the National Association of Universities and Institutions of Higher Education (Anuies, 2013), only $30 \%$ of women opt for a STEM career, the objective of this work is to determine data to understand the factors that define the motivation of women of STEM careers in three public universities: Autonomous University of Baja California, Polytechnic University of Baja California and University of Sonora Estate.

\section{Young people and their interest in studying}

A number of researches point to some gender differences in the choice of higher education studies Holman et al., 2018). The published studies on this subject offer numerous explanations and adopt diverse methodological approaches, but the common factors to be taken into consideration are social, economic, ethnic context; family context; gender issues; influence of schools and quality of teaching; interests and aptitudes for science (Ellis et al.. 2016. Literature in this field has highlighted the influence of the family context on the motivation of the student's education and progress, and the importance of positive relationships between parents and children as a fundamental element for the adaptation and success in the educational context (Munk, 2011).

\section{The underrepresentation of women}

An investigation by (Cheryan et al..,2017), summarizes the reasons for the underrepresentation of women in the STEM area: biological differences between men and women, lack of scientific preparation of teachers, poor attitude of women towards science as a consequence of a lack of positive experiences since childhood, the absence of female role models to follow in the areas of science and engineering, irrelevant curricula for women, pedagogy of science teaching favoring male students, "cold environments" for women in science classes; cultural pressure on women to adjust to traditional gender roles and an inherent view of the masculine world in scientific epistemology.

\section{Progress of women in engineering}

According to the National Science Foundation, National Center for Science and Engineering Statistics 2017; (NSF) in the United States, women's participation in undergraduate degrees has increased gradually from 1970 to 2013, from $43 \%$ to $57 \%$. While in the case of Mexico, it was possible to increase from $16 \%$ to $49 \%$, and the same happens 
at the postgraduate level. The enrollment of women studying in the STEM area shows a significant increase from $28 \%$ in 1970 to $50 \%$ in 2015. The results show that women in the United States have reached a percentage close to or greater than 50 $\%$, as an indicator of the progress in the inclusion of women and an increase in diversity.

In the case of Mexico according to ANUIES, in 2013 (women constituted $49 \%$ of bachelor degrees and $46 \%$ of P.H. D's in all fields. In the STEM areas, women represent $30 \%$ of the undergraduate and $28 \%$ of postgraduate populations. Compared to 1970 with $13 \%$ of undergraduates and $7 \%$ in postgraduates. There are few women who excel in the areas of science and technology according to the National Council of Science and Technology (Conacyt, 2012), 8.245 women and 15.072 men are registered in the National System of Researchers (SNI). This situation could be a consequence of family structure; in Mexico according to the Organization for Cooperation and Development (OECD, 2015), $34 \%$ of children said that their parents expect them get jobs related to the STEM area, while only $13 \%$ of women expressed that their parents expect them to work in these areas.

In the report of the first National Meeting of Young People in Engineering in November of 2015, regarding the presence of women in engineering, it was pointed out that there is still taboo-based gender discrimination such as women's intellectual incapacity given the greater male presence and that this limits the opportunities in the labor market. "It is not a matter of equity if not equality", it was settled, and the government is also urged to invest in a program of motivation for science and technology from the lower levels of education.

The OECD report, "The ABC of Gender in Education," shows progress in gender equality in member countries. In some disciplines, women have gained more ground than men. $56 \%$ of university students in OECD countries are women and, according to various studies, women have demonstrated better performance, motivation, discipline, as well as a varied use of study strategies, in careers that traditionally have not been considered suitable for them (Duarte et al.., 2011). However, a gender gap persists in engineering career choices. In figure 2, according to OECD 2015, only one in five students who graduated in the engineering fields were women. The lack of gender equality in these areas is oriented to the absence of role models of women scientists and engineers in education (Blickenstaff, 2005).

\section{The importance of women scientists as role models}

Several studies claim that fewer women than men decide to enter careers in STEM areas (Hill et al., 2010). However, female students have shown better overall performance compared to their male counterparts (Rincón and George-Jackson, 2016). One way to encourage women to study in the STEM area is to show them role models of successful women in those areas (Lockwood, 2006). It is increasingly accepted that female role models are effective in inspiring girls like the books of the National Academy of Science and "Adventures of Women in Science" (Cheryan et al., 2011)

\section{STEM as a tool to encourage engineering studies}

With the aim of promoting the insertion of women in the productive sector as a fundamental element for economic development, the OECD establishes educational policies for Latin America based on the STEAM model. In this manner, combines many different types of content that accentuate the educational strategies with the aim of motivating and avoiding desertion of women in engineering, besides, to understand the complex world, adopt the current signatures, acquire knowledge, experience, and to become leaders of their societies and nations.

Strategies include internship programs in companies for the practical application of knowledge acquired in school, implementation of experiential workshops, critical reading, debates, discussion 
tables, critical thinking, science fairs and competitions, clubs and research networks, as well as workshops and talks of successful mentors in the STEM areas.

A step further is the teaching of Science and Art in an integrated manner, to be able to manage subjects of universal culture. Figure 1, with STEAM at its center, illustrates its competent experts and their activities that improve the wisdom, understanding, and knowledge of the students.

\section{Methodology}

To reach the objectives of this study, a questionnaire was applied to 426 enrolled women out of a total of 1421 students on STEM careers from the three universities, in order to investigate intrapersonal and interpersonal factors that may influence the choice of STEM courses, the questionnaire Relevance of Science Education questionnaire (ROSEQ) was applied; this instrument is composed of closed questions (Schreiner and Sjoberg, 2004). For the purposes of this paper, 5 questions were selected to investigate the experiences of learning in school, the inspiration for the choice of career, as well as the future expectations of employment.

For the processing of the information obtained from the questionnaires we used the SPSS software, a statistical package for data analysis with application in social and economic sciences research.

\section{Results}

Results showed the career choice profile through the students' responses to some of the items in the ROSE-Q, which raises the importance of the existing personal beliefs, the importance of people and future employment expectations.

When students were asked about their decision to pursue a career in engineering, they provided their opinions, most of which are linked to family, cultural background and particular aspirations.

\section{Question 1. What motivated you to choose your career?}

$38 \%$ of students stated that their choice for engineering was informed, as they investigated the different courses of the program and the graduation profile. In addition, 18\% chose their career based on job opportunities and activities in the field of work and it is surprising to find that for $25 \%$ of them, engineering was not their first choice, but they started a career in engineering, convinced by these opportunities. Only 19\% stated that their engineering inclination was due to their preference

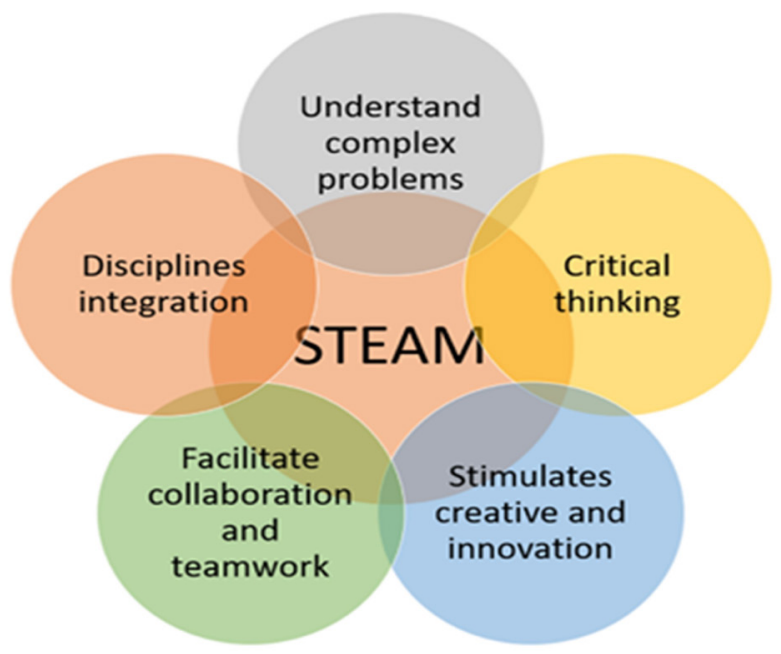

Figure 1. Activities of the experts that improve the wisdom, understanding, and knowledge of the students. 
and mastery of mathematics. Being skilled in mathematics has always been a major incentive to study engineering; currently STEM represents a platform that encompasses science and technology with the study of mathematics.

\section{Question 2. How influential the following people were on your career choice?}

$59 \%$ of the students have their parent's support. The above shows that families are changing their ideas of women's traditional role, to whom they strongly suggest and support, (Perkrun et al., 2014). Women who decided on STEM careers were those who grew up in a family environment where the parents dedicated themselves to these disciplines and could solve their concerns. 29\% expressed feeling supported by their friends, and the lowest percentage was represented by teachers, indicating the need to strengthen the awareness of faculty members towards STEM activities.

\section{Question 3. Is there a female role model to follow?}

In the question regarding the existence of a female role model to follow (Figure 4), answers showed that 75 percent of the women did not have one, 19 percent said they were motivated by their teachers and only 6 percent said they had an engineer in their families. For college students, having a role model can influence their career choice as well as their motivation to keep studying over the course of the program (Lockwood, 2006), as well as the inspiration for achieving better professional development conditions by obtaining a degree in engineering. Having a role model to follow provides important additional benefits, especially in women, influenced by attitudes, achievements, and support from others (Henes et al.., 1995).

\section{Question 4. What is your goal?}

When $59 \%$ of student's state that their goal by studying engineering is to demonstrate that they can do it, it becomes clear that most students are men and that women struggle to succeed in an adverse environment. In the literature, it is found that female engineering students are discouraged by strong competition. (Chesler and Chesler, 2002). $25 \%$ said that their goal was to apply to engineer and to do projects and only $8 \%$ stated that their goal was to become entrepreneurs and to start their own companies.

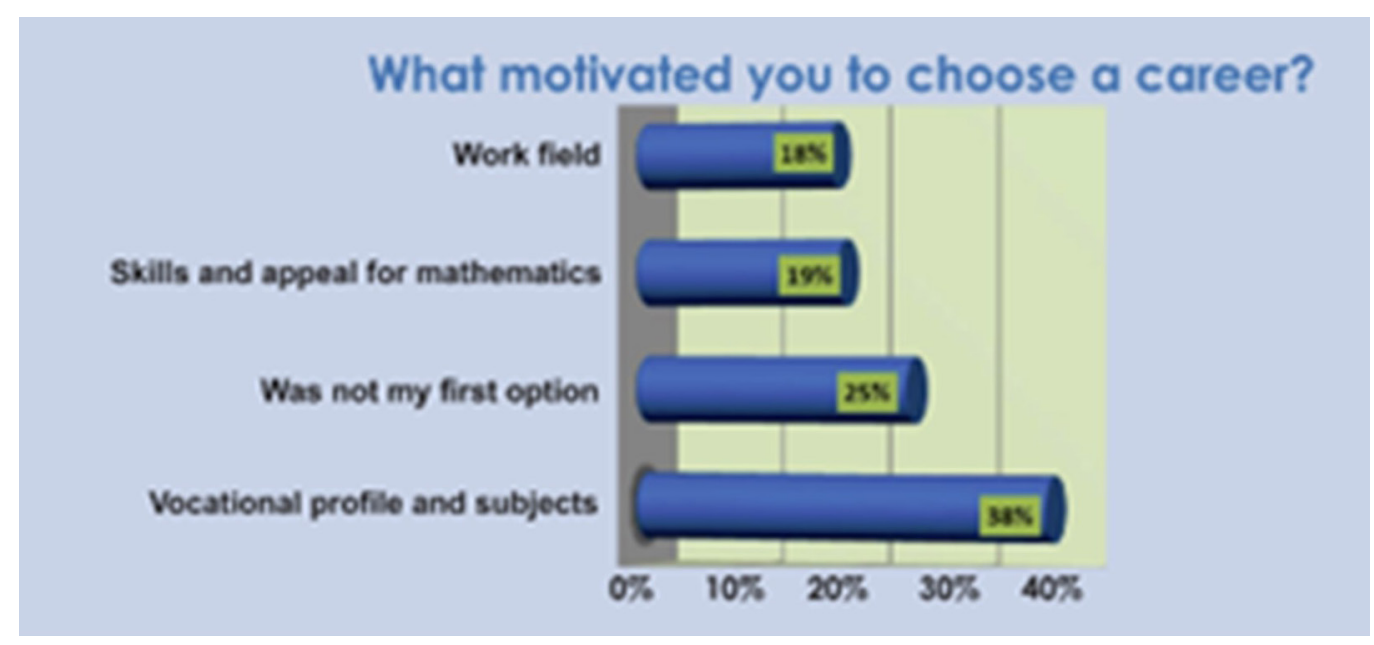

Figure 2. Source: Prepared. 


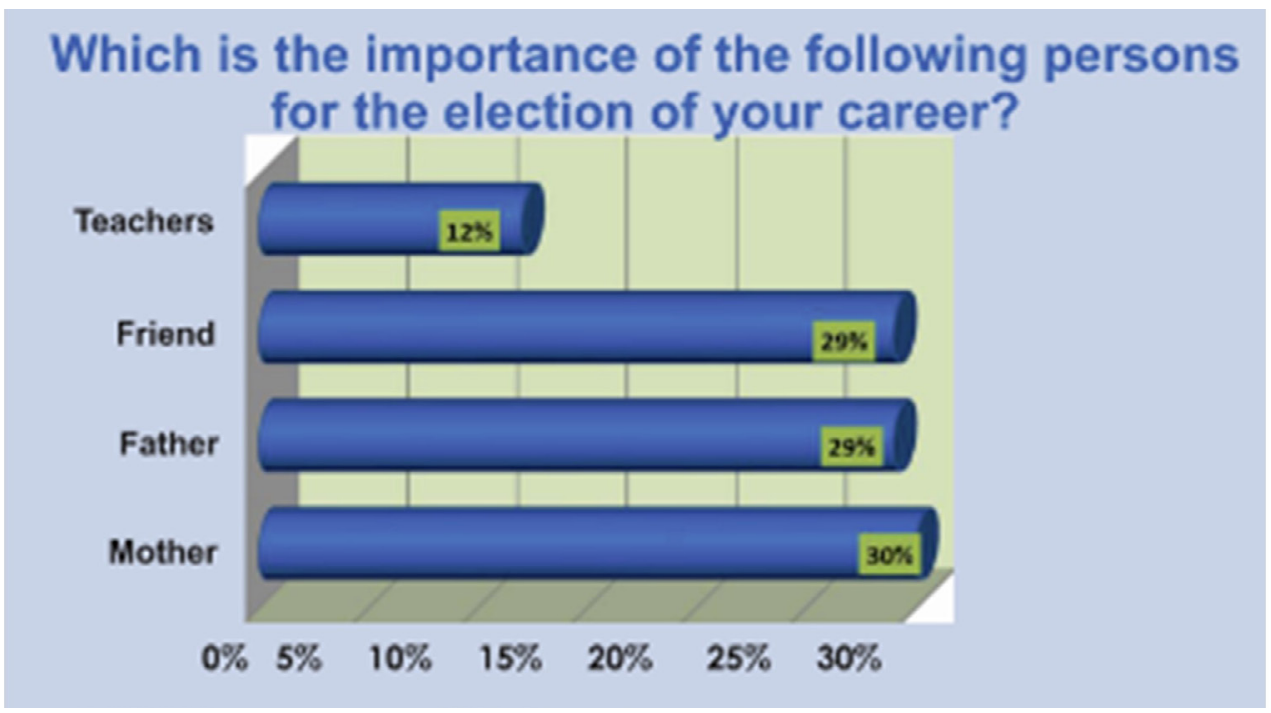

Figure 3. Source: Prepared.

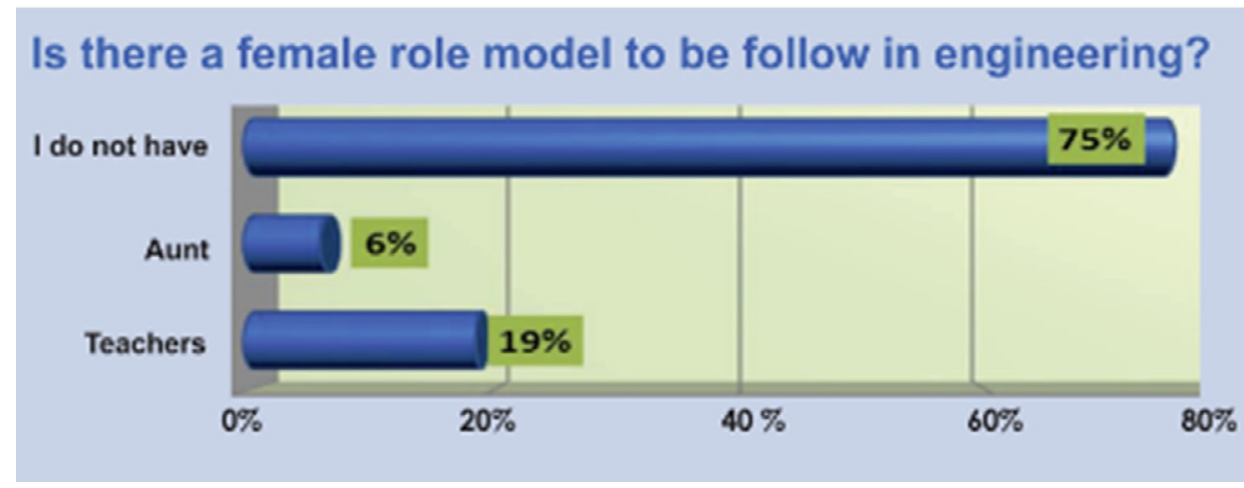

Figure 4. Source: Prepared.

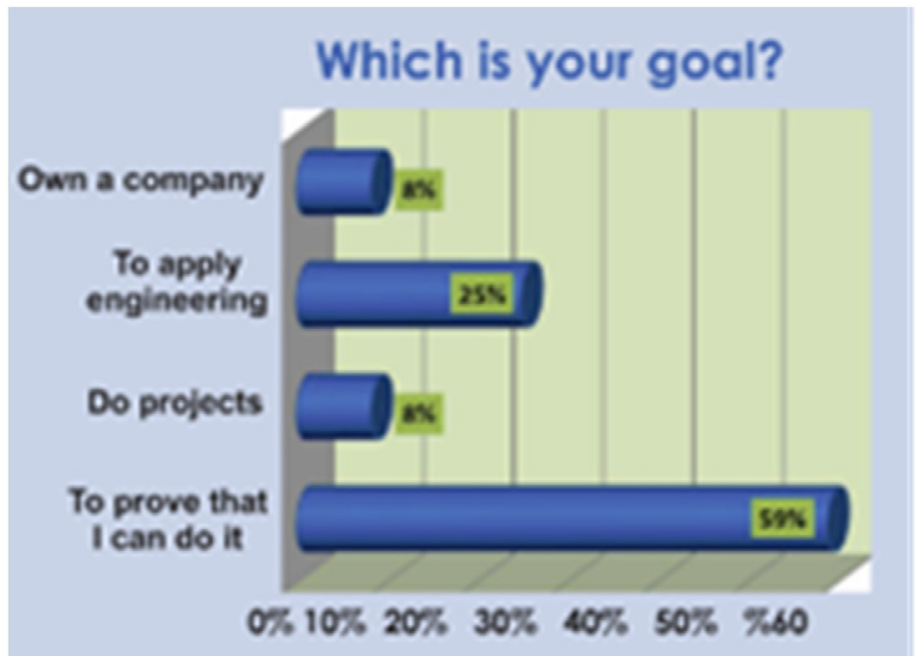

Figure 5. Source: Prepared. 


\section{Question 5. Where would you want to work?}

$50 \%$ expressed their desire to work in a company. $32 \%$ said they wanted to start their own company. While, $6 \%$ expressed interest in research, which would imply continuing their education in postgraduate programs. Only $6 \%$ showed an interest in teaching and $6 \%$ for working in a government agency. This shows, once again, a change in the perception of the role of women, since only $12 \%$ showed interest in employment considered more traditional for women as teachers or government employees. According to Cólas and Jiménez (2006), spaces must be created in which social practices between genders are transformed to avoid gender discrimination in the workplace.

\section{Conclusions}

As a conclusion, we observed that women are increasingly informed when choosing a career based on future expectations of employment, as well as having a greater ability for mathematics.
In the family aspect, there was a greater conviction of women's opportunities in the areas of science and technology, as the results show that families supported them in a large percentage when choosing a career in the STEM area.

Seventy-five percent of the students said they did not have a female role model to follow, just as a small percentage of the students had a female engineer in their families. According to Hill et al., (2010), one of the factors that have inspired many women to choose engineering careers is to have examples of successful women in this field of knowledge.

Engineering students of the three universities have plans to use their knowledge and skills in the future to contribute to the development of the country Richard et al. (2016).

It is necessary to combine efforts between the Secretary of Public Education and the private sector, to implement programs in schools, that allow contact with successful women in science and engineering with the students in order to promote interest on careers in the STEM area and increase the number of women enrolled.

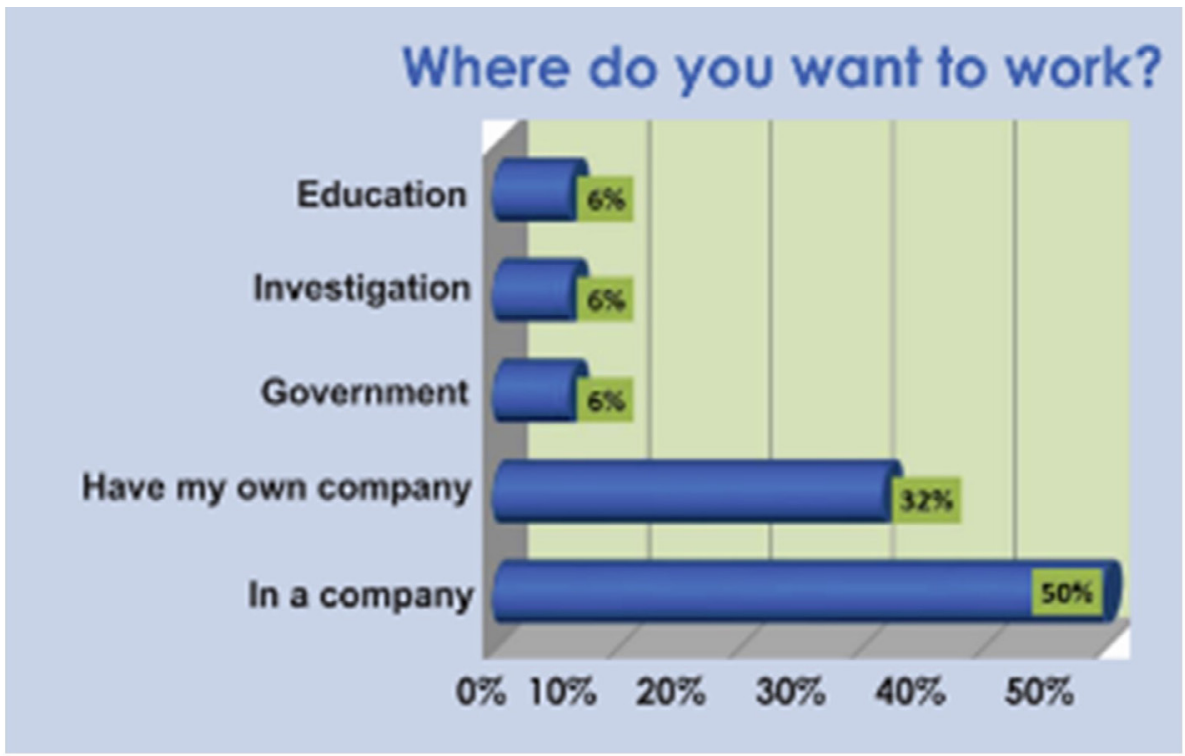

Figure 6. Source: Prepared. 
According to Ramírez and Bermúdez (2015), there is a lot of work to be done generating information from gender studies, and new lines of research are necessary to understand the changes between the actors and the new institutional environments in higher education in Mexico.

Among the OECD's recommendations for Latin America, it is the necessity to implement STEM models with the aim of improving gender differences and recruiting more talented female students in science-related fields as a platform for the economic development of countries.

\section{Acknowledgements}

We would like to thank Conacyt, Autonomous University of Baja California, State University of Sonora and Polytechnic University of Baja California, for all the support in the development of the present work.

This work was financially supported by Conacyt under the Grant Number 280473

\section{References}

Anuies (2013). Anuario Estadístico: ciclo escolar 2013-204. México D. F.: Asociación Nacional de Universidades e Instituciones de Educación Superior.

Blickenstaff, J. (2005). Women and science careers: leaky pipeline or gender. Gender and Education, 17. Taylor \& Francis. https://doi. org/10.1080/09540250500145072

Brotman, J. S.; Moore, F. M. (2008). Girls and science: A review of four themes in the science education literature. Journal of Research in Science Teaching, 45(9), 971-1002. https://doi. org/10.1002/tea.20241

Cheryan, S.; Oliver, J.; Vichayapai, M.; Drury, J; Saenam, K. (2011). Do female and male Role Models Who Embody STEM Stereotypes Hinder Women' Anticipated Success in STEM. Social Psychological and Personality Science, 2(6), 656-664. https://doi. org/10.1177/1948550611405218
Cheryan, S.; Ziegler, S. A.; Montoya, A. K; Jiang, L. (2017). Why are some STEM fields more gender balanced than others? Psychological Bulletin, 143(1), 1-35. https://doi.org/10.1037/ bul0000052

Chesler, N; Chesler, M. (2002). Gender-informed mentoring strategies for women engineering scholars: On establishing a caring community. Journal of Engineering Education, 91(1), 4955. https://doi.org/10.1002/j.2168-9830.2002. tb00672.x

Colás, P; Jiménez, R. (2006). Tipos de conciencia de género del profesorado en los contextos escolares. Revista Educación. http://www.revistaeducacion.educacion.es/re340/re340 15. pdf

Conacyt (2012). Anuario estadístico México D. F.: Consejo Nacional para la Ciencia y la Tecnología. http://www.conacyt.mx/siicyt/index. php/centros-de-investigacion-conacyt/indicadores-cientificos-y-tecnologicos/indicadoresactividades-cientificas-y-tecnologicas/2594ind-2012/file

Duarte, M.; Sevilla, J.; Gutiérrez, S; Galaz, J. (2011). Expectativas y capital académico de estudiantes de nuevo ingreso a ingeniería en Mexicali, México: Discusión desde la perspectiva de género. Ingenierías, 14(51), 22-30.

Ellis, J.; Fosdick, B. K; Rasmussen, C. (2016). Women 1.5 times more likely to leave stem pipeline after calculus compared to men: lack of mathematical confidence a potential culprit. PLOS One, 11(7), 1-14. https://doi.org/10.1371/journal.pone.0157447

Henes, R.; Bland, M. M.; Darby, J.; McDonald, K. (1995). Improving the academic environment for women engineering students through faculty workshops. Journal of Engineering Education, 84(1), 59-67. https://doi. org/10.1002/j.2168-9830.1995.tb00147.x

Hill, C.; Corbett, C. St; Rose, A. (2010). Why So Few? Women in Science, Technology, Engineering, and Mathematics. American Association of University Women. http://www.aauw. 
org/files/2013/02/Why-So-Few-Women-inScience-Technology-Engineering-and-Mathematics.pdf

Holman, L.; Stuart-Fox, D.; Hauser, C. E. (2018) The gender gap in science: How long until women are equally represented? PLoS Biol, 16(4), e2004956. https://doi.org/10.1371/journal.pbio.2004956

Lockwood, P. (2006). 'Someone like me can be successful': Do college students need samegender role models? Psychology of Women Quarterly, SAGE 30(1), 36-46. https://doi. org/10.1111/j.1471-6402.2006.00260.x

McConnell, T.; Parker, J.; Eberhardt, J. (2016). Problem-Bases Learning in the Life Science. SSTA press.

Munk, M. (2011). Educational choice: Which mechanism are at stake? Copenhagen: Centre for Mobility research, Department of Political Science, Aalborg University.

National Science Board. (2014). Science and Engineering Indicators. https://www.nsf.gov/ statistics/

National Science Foundation, National Center for Science and Engineering Statistics (2017). Women, minorities, and persons with disabilities in science and engineering: 2017. Special Report NSF, 17-310. Arlington: www.nsf.gov/ statistics/wmpd/

OCDE (2015). The ABC of Gender in Education. OCDE.

Pekrun, R.; Cusack, A.; Murayama, K.; Elliot, A. J.; homas, K. (2014). The power of anticipated feedback: effects on students' achievement goals and achievement emotions. Learning and Instruction, 29, 115-124. https://doi. org/10.1016/j.learninstruc.2013.09.002
Primer Encuentro Nacional de Jóvenes en Ingeniería. http://www.ai.org.mx/ai/index. php/9-uncategorised/546-primer-encuentronacional-de-jovenes-en-la-ingenieria

Pruitt, S. L. (2014). The Next Generation Science Standards: The features and challenges. Journal of Science Teacher Education, 25(2), 145-156. https://doi.org/10.1007/s10972-014-9385-0

Ramírez, D; Bermúdez, F. (2015). Avances, retos y desafíos: aproximación al estado del conocimiento de los estudios de género en educación superior en México. Entreciencias, 3(6). https://doi.org/10.21933/J.EDSC.2015.06.102

Razo, L. (2008). La inserción de las mujeres en las carreas de ingeniera y tecnología. Perfiles Educativos, 30(121).

Felder, R. and Brent, R. (2016). Teaching and Learning STEM: A Practical Guide. Publisher Wiley.

Rincón, B. E.; George-Jackson, C. E. (2016). Examining department climate for women in engineering: The role of STEM interventions. Journal of College Student Development, 57(6), 742747. https://doi.org/10.1353/csd.2016.0072

Scantlebury, K. and Baker, D. (2007). Gender issues in science education research: Remembering where the difference lies. In S. K. Abell and N. G. Lederman (eds.), Handbook of research on science education (pp. 257-285). Mahwah: Lawrence Erlbaum.

Schreiner, C. y Sjoberg, S. (2004). Sowing the seeds of ROSE. Background, Rationale, Questionnaire Development and data Collection for ROSE (The Relevance of Science Education). Oslo: University of Oslo.

Universidad Autónoma de Baja California (2013). Anuario "Encuesta anual de ambiente organizacional". http://www.uabc.mx/planeacion 